Uniwersytet Kazimierza Wielkiego

s.tomasik@yandex.ru

\title{
KOLOKWIALIZACJA NAZW HANDLOWYCH LEKÓW O PEWNEJ NOWEJ TENDENCJI ONOMASTYCZNEJ
}

Słow a tematyc zne: chrematonimia, nazwy handlowe leków, kolokwializacja

Z roku na rok obserwuje się coraz większą skłonność Polaków do leczenia się samemu, bez konsultacji z lekarzem lub farmaceutą. J. Pluta, prezes Polskiego Towarzystwa Farmaceutycznego, uważa, że 80\% Polaków leczy się samodzielnie, a statystyczny Polak rocznie kupuje 34 opakowania leków wydawanych bez recepty, $20 \%$ obywateli naszego kraju przyjmuje natomiast jedną tabletkę przeciwbólową tygodniowo ${ }^{1}$. Co trzeci Polak kupuje leki pod wpływem reklamy telewizyjnej lub radiowej ${ }^{2}$. Z badań wynika ${ }^{3}$ także, że większość polskich pacjentów w ciagu ostatniego roku choć raz szukała informacji o leku bez recepty. Głównymi źródłami informacji były Internet, telewizja, rodzina i znajomi. Coraz częściej i coraz powszechniej doceniani są domowi „specjaliści” i niezawodny „doktor Google".

Moim celem jest zwrócenie uwagi na nową tendencję onimiczną, jaką obserwuje się we współczesnym przemyśle farmaceutycznym i we wspomagających go działaniach marketingowych. Chodzi tu o kolokwializację nazw handlowych leków. Mówiąc o kolokwializacji, mam na myśli kilka zjawisk nazewniczych. Po pierwsze, chcę $\mathrm{w}$ ten sposób określić pojawianie się na rynku farmaceutycznym produktów o bardzo czytelnych, przejrzystych strukturalnie nazwach. Po drugie, przez kolo-

${ }^{1}$ Przyczyn powiększania się listy leków wydawanych bez recepty może być wiele. W ostatnich latach w społeczeństwie Zachodu obserwować można wzrost wiedzy medycznej i rosnącą troskę o komfort ciała. Zwiększa się liczba dostępnych produktów w aptekach i — co ważne - pojawiają się środki na „nowe” dolegliwości, często stanowiące uboczny skutek terapii (np. probiotyki) lub będące następstwem gwałtownych procesów modernizacyjnych (specyfiki uspokajające i pomagające radzić sobie ze stresem, przemęczeniem, dekoncentracją). Problem tego, gdzie tkwi przyczyna rosnącego popytu na lekarstwa (wydawane na receptę i dostępne bez niej), wykracza poza skromne ambicje niniejszego szkicu; por. Moskal 2013.

2 Polowa pacjentów ignoruje zalecenia lekarzy, http://www.rynekaptek.pl/farmakologia/farmakoterapia-polowa-pacjentow-ignoruje-zalecenia-lekarzy,17307.html (dostęp 24 V 2017).

${ }^{3}$ Por. Moskal 2013. 
kwializację rozumieć będę działania producentów zmierzające do ułatwienia „zrozumienia" przez kupującego nazwy oferowanego mu specyfiku. Chodzi mi o zabiegi podejmowane przez twórców reklam, których celem jest ułatwienie kupującemu odnalezienia motywacji znaczeniowej nazwy (rozszyfrowanie jej znaczenia strukturalnego). Po trzecie wreszcie, kolokwializację nazw handlowych leków odnosić będę do przypadków, w których w reklamach telewizyjnych i radiowych pojawia się stylizowanie języka na potoczne (i ocierające się o granicę wulgarności) mówienie o ludzkiej fizjologii.

Warto przede wszystkim zwrócić uwagę na to, że lekarstwa są dziś łatwo dostępne. Coraz więcej produktów leczniczych jest też rejestrowanych jako leki wydawane bez recepty. Często są to produkty pomagające na błahe dolegliwości, których objawy mogą złagodnieć lub ustąpić po kilku dniach samodzielnie aplikowanej terapii. Rosnąca liczba leków dostępnych bez recepty oznacza, iż stale zwiększa się rejestr nazw leków, które ma zapamiętać konsument, nie zaś lekarz. Użytkownikiem nazwy leku bez recepty jest pacjent, któremu w wyborze nie zawsze pomaga specjalista. Wiadomo bowiem, że leki bez recepty sprzedawane są także poza apteką, np. w supermarkecie, na stacji benzynowej, a nawet w automacie z lekami (lekomacie ${ }^{4}$ ). W wielu sytuacjach osoba kupująca specyfik dostępny bez recepty przestaje być pacjentem (a jest nim w aptece), staje się zwykłym klientem. Tak dzieje się np. na stacji benzynowej, gdzie farmaceutę zastępuje sprzedawca lub osoba nalewająca paliwo. Sprzedawca na stacji benzynowej (lub w innym punkcie handlowo-usługowym) w nader ograniczonym zakresie przejmuje rolę farmaceuty, udziela tylko najprostszej ,porady”, podpowiada, co wybrać. Lek staje się takim samym produktem, jakim jest napój gazowany, batonik czy kolorowy magazyn. Obniża to jego status jako produktu, który wcześniej dystrybuowany był niemal wyłącznie w wyspecjalizowanych placówkach (aptekach).

Jak wspomniałam, kupując lek na stacji benzynowej, nie możemy liczyć na fachową poradę dotyczącą składu, działania czy interakcji leków. Można się więc zastanowić, jak taką sytuację pogodzić z komunikatem-ostrzeżeniem, umieszczanym obowiązkowo w każdej reklamie leku. Przypomnę jego brzmienie: „Przed użyciem zapoznaj się z treścią ulotki dołączonej do opakowania bądź skonsultuj się z lekarzem lub farmaceuta, gdyż każdy lek niewłaściwie stosowany zagraża Twojemu życiu lub zdrowiu". Wymagana konsultacja ze specjalista jest zamieniana na krótką rozmowę ze sprzedawca, którego wyjaśnienie ogranicza się zwykle do wskazania marki produktu, wielkości opakowania i ceny. Czym zatem kierują się konsumenci, dokonując wyboru leku (szczególnie takiego, który dostępny jest poza apteka)? Wydaje się, że jednym z najważniejszych źródeł informacji o farmaceutykach jest reklama. To ona przejmuje funkcję poradnika. Informacje przedstawione w spotach

${ }^{4}$ Lekomaty są nowym kanałem dystrybucji leków. Ich wprowadzenie świadczyć może nie tylko o wyłączaniu specjalistów z dystrybucji leków, ale także o szerszym procesie, który nazwałabym współczesną dehumanizacją leczenia. 
reklamowych kierowane są do szerokiej i niezróżnicowanej grupy odbiorców. Ich celem jest ułatwienie klientowi samodzielnego dokonywania wyboru.

Analiza współczesnych nazw handlowych leków prowadzić może do wniosku, że występują w nich przede wszystkim dwie główne strategie nazewnicze. Strategie te są pochodna postrzegania zawodu lekarza, procesu leczenia i sposobu działania leków. Pierwsza z nich to strategia, dla której charakterystyczne są skomplikowane, niejasne (i „nierozkładalne”) dla przeciętnych pacjentów nazwy handlowe leków. Można uznać, że z punktu widzenia głównych użytkowników nazw handlowych leków, tj. pacjentów, są to nazwy niemotywowane. Niekiedy są one postrzegane jako przypadkowe ciagi liter lub jako obco brzmiące (i niezrozumiałe) słowa. Takie konstrukcje nazewnicze uznawane są zwykle za element języka specjalistycznego. Formacje te są zazwyczaj dla pacjentów mało użyteczne: elementy nazw tego typu pochodzą z greki lub łaciny, co czyni je czytelnymi dla niewielu. Można jednak uznać, że w przekonywaniu klientów o skuteczności specyfiku działa tutaj zasada: leki są złożonymi produktami, a leczenie jest skomplikowanym procesem, który nazwy leków muszą w swoim brzmieniu i budowie odzwierciedlać.

W nazwach niemotywowanych producent (i podmiot odpowiedzialny za działania marketingowe) zakłada u pacjenta postawę całkowitego zaufania do osób zawodowo zajmujących się leczeniem. To właśnie personel medyczny potrafi posługiwać się językiem medycznym, a więc i ,trudnymi” (do zapamiętania i powtórzenia) nazwami leków. Tego typu nazwy (czytelne dla nielicznych niespecjalistów) będę określać mianem tradycyjnych. Ich cechą będzie wbudowane ,niezrozumienie", które pozwala utrzymywać dystans pomiędzy pacjentem a światem medycyny i farmacji. Dla przeciętnego użytkownika języka i klienta apteki nazwami niemotywowanymi (tradycyjnymi, ,niezrozumiałymi”) mogą być np.: APAP, Atrovent, Vigantoletten, Mirzaten, Axotret, Coliproz, Belara, Nebilet, Infarix, Izotek, Teflexo, Dexilant, Jaydess, Nimesil, Humalog, Dicortineff, Milurit, Hexacima, Vivace, Valzek, Trittico ${ }^{5}$. D. Kulesza, analizując reklamy różnych produktów, zauważa, że: „tajemnicze i nieznane zazwyczaj odbiorcy znaczenie słów podkreśla wyjątkowość oferowanego produktu oraz świadczy o jego wysokiej jakości. Takie komunikaty nie informują o zaletach produktu, lecz mają za zadanie stwarzać wrażenie nowoczesności czy innowacyjności”" .

Prawidłowa wymowa ,tradycyjnych” (niemotywowanych) nazw leków może dla przeciętnego pacjenta stanowić problem. Jeśli nazwa jakiegoś specyfiku nie jest zrozumiała dla pacjenta (nie ma dla niego znaczenia strukturalnego), to niewatpliwie będzie mu ona sprawiała kłopoty w codziennym użyciu (np. w przekazaniu nazwy

5 W rzeczywistości w wielu, ,tradycyjnych” nazwach handlowych leków można wskazać motywację. Analiza budowy nazw leków i wskazanie najbardziej popularnych modeli nazewniczych (odsłonięcie motywacji nazw) będzie tematem innej mojej pracy.

${ }^{6}$ D. Kulesza, Językowe środki perswazji w reklamie, http://pu.wsptwp.eu/wp-content/uploads/2011/03/J\%C4\%99zykowe-\%C5\%9Brodki-perswazji-w-reklamie.pdf (dostęp 10 XII 2017). 
leku innym osobom). Trudność w posługiwaniu się taką nazwą leku (tradycyjna) może prowadzić do celowego lub niezamierzonego jej zniekształcania ${ }^{7}$.

Drugą i stosunkowo nową strategią nazewniczą jest wspomniana wcześniej kolokwializacja nazw handlowych leków. Producenci leków zdają się brać w niej pod uwagę potrzeby tej grupy klientów, która nie zawsze chce korzystać z wiedzy specjalistów i woli aplikować sobie sama niezbyt skomplikowaną terapię. Wydaje się, że „chwyt”, który określam jako kolokwializację nazw handlowych leków, ma ułatwiać wybór leków pacjentom nieposiadającym odpowiedniego wykształcenia medycznego. W strategii kolokwializacji nazwy leków są celowo konstruowane (dobierane) w taki sposób, aby ich użytkownicy nie mieli większego problemu z rozróżnieniem obiektów, które te onimy wskazują, ale także po to, aby kupujący, kierując się swoją przeciętną wiedzą medyczną i sugestiami producenta, bez trudu potrafili wybierać potrzebne im produkty lecznicze.

Ułatwienie wyboru stwarza z całą pewnością czytelna dla klienta motywacja nazwy leku, jej strukturalna „przejrzystość” (wyrazistość budowy). Można więc uznać tę grupę jednostek skolokwializowanych za nazwy motywowane (z punktu widzenia przeciętnego użytkownika). Ów klient może bez trudu znaleźć motywację takich nazw leków jak: Antypot, Cholester, Hemorol, After, 2 KC, Liporedium, Maść na odciski, Aromatol, Gripblocker, Grypostop, Niko-lek, Lekosen, Inhalol, Nervosol, Tabex, Anticholesteron, Tabletki uspokajajace, Nervomix. Strukturalna przejrzystość (zrozumiałość) tego rodzaju nazw leków może czasami wydawać się wyolbrzymiona. Leki kojarzą się zwykle ze specjalistycznym procesem ich wytwarzania, z niepewnością diagnozowania choroby i z trudną terapią. Tymczasem nazwy niektórych specyfików mogą przypominać nazwy innych produktów dostępnych w handlu, a nie leków. Część przywołanych nazw wyraźnie naśladuje poetykę domowych opisów, które pacjenci samodzielnie umieszczają na opakowaniach, gdy nazwa handlowa leku nie kojarzy się z dolegliwościami. Wprowadzając swoje opisy (np. „na nerwy”, „na ból w krzyżu”), pacjenci niejako „tłumaczą” skomplikowane nazwy na styl charakterystyczny dla codziennego mówienia o dolegliwościach („łamie mnie w krzyżu”, „muszę wziąć coś na nerwy”).

Współcześni konsumenci używają wielu nazw niemotywowanych lub takich, których motywacja nie jest dla nich całkiem jasna. Przykładem niech będą takie oto nazwy: W5, Ikea, Tesco, Ajax, Lipton. Użytkownicy „,nauczyli się” ich, przywykli do nich. Trudne nazwy leków (te „tradycyjne”, np. Acenocumarol, Haloperidol, Lexapro) nie dają się łatwo oswoić, dlatego duże koncerny farmaceutyczne wychodzą naprzeciw tym trudnościom, proponując nazwy „łatwiejsze”. Jedną z propozycji określiłabym jako „wariacje” na temat nazw tradycyjnych. Owe „wariacje” zachowują pewne cechy nazwy tradycyjnej (np. złożoną strukturę), lecz jeden z ele-

\footnotetext{
${ }^{7}$ Celowe i niezamierzone zmiany nazw leków to temat, który podejmuję w innym miejscu.

${ }^{8}$ Motywacja może być związana z przeznaczeniem leku lub inną informacją dotyczącą preparatu, np. wskazaniem obszaru, w obrębie którego dany lek działa.
} 
mentów nazwy jest „oswajany”, kolokwializowany. Wydaje się, że taki zabieg przekształca lek w towar i zbliża go do produktów codziennego użytku. Oswajany (kolokwializowany) jest element obcojęzyczny, np. pochodzący z języka łacińskiego lub greki. Jego miejsce zajmuje cząstka wzięta z języka polskiego lub angielskiego ${ }^{9}$. Dzięki takiemu „oswojeniu” nazwa może łatwiej stać się zrozumiała (umotywowana) dla klienta, a więc i bardziej użyteczna.

Nazwa to jedno z głównych narzędzi wspomagających współcześnie dystrybucję towarów. W wariacji na temat nazwy klasycznej można odnaleźć przejaw chwytu reklamowego, który znany jest jako dopasowywanie towaru do użytkownika, dostosowywanie produktu do potrzeb klienta. Producent leku i podmiot odpowiedzialny za strategię marketingową, dobierając odpowiednią nazwę, dają klientowi poczucie, że oferowany produkt jest przygotowany specjalnie dla niego, dostosowany do jego potrzeb, „uszyty na miarę”. W kolokwializacji nazw leków dopasowaniem do klienta byłoby zasugerowanie budową przekazu takiego oto komunikatu: „kliencie, spójrz, mówimy twoim językiem, więc rozumiesz nas”. J. Bralczyk, analizując komunikaty reklamowe, podkreśla ważną rolę „,czegoś swojskiego”, uważa też, że tę „swojskość” można skutecznie osiagnać za pomocą języka (2004: 11-12).

Zjawiskiem nierozerwalnie związanym z rozpatrywaną tu kolokwializacją nazw handlowych leków jest przenikanie stylizacji kolokwialnej do reklam produktów leczniczych. Zgodnie z komunikatem Głównego Inspektoratu Farmaceutycznego „reklamą produktu leczniczego jest działalność polegająca na informowaniu lub zachęcaniu do stosowania produktu leczniczego, mająca na celu zwiększenie: liczby przepisywanych recept, dostarczania, sprzedaży lub konsumpcji produktów leczniczych"10. Taka reklama może mieć dwie podstawowe grupy adresatów. Wyróżnić można mianowicie reklamę skierowaną do szerokiej publiczności (do przeciętnych odbiorców, pacjentów) oraz do osób uprawnionych do wystawiania recept lub prowadzących obrót produktami leczniczymi (lekarzy, farmaceutów). Ograniczenia dotyczące reklamowania produktów leczniczych zostały określone w formie ustawy i stosownego rozporządzenia ${ }^{11}$.

Reklama produktu leczniczego ${ }^{12}$ nie może m.in. wprowadzać w błąd konsumentów, powinna prezentować dany produkt obiektywnie oraz informować o jego racjonalnym stosowaniu. Nie może także polegać na oferowaniu lub obiecywaniu jakichkolwiek korzyści w zamian za nabycie produktu leczniczego. Nie powinna być

${ }^{9}$ Przykłady zostaną zaprezentowane w dalszej części artykułu.

${ }^{10}$ Reklama produktów leczniczych, https://www.gif.gov.pl/pl/nadzor/reklama-produktow-leczn/476,Reklama-produktow-leczniczych.html (dostęp 19 I 2018).

${ }_{11}$ Zob. Prawo farmaceutyczne z 2008 r. oraz rozporządzenie Ministra Zdrowia z dnia 21 listopada 2008 r. w sprawie reklamy produktów leczniczych.

${ }_{12}$ Warto zwrócić uwagę, że reklama suplementu diety, produktu często traktowanego przez pacjentów na równi z lekiem, nie podlega tak ścisłym regulacjom prawnym. Nadzór nad tego typu produktami prowadzi Główny Inspektorat Sanitarny. Z punktu widzenia ustawodawcy suplementy diety są więc traktowane jak produkty spożywcze. 
również kierowana do dzieci. Produkt leczniczy nie może być reklamowany przez osoby znane publicznie, naukowców, osoby posiadające wykształcenie medyczne lub farmaceutyczne czy też sugerujące posiadanie takiego wykształcenia. Nie może również sugerować, że możliwe jest uniknięcie porady lekarskiej lub zabiegu chirurgicznego, zwłaszcza przez postawienie diagnozy lub zalecanie leczenia w drodze korespondencyjnej.

Komunikaty zawarte w tego typu reklamach nie moga prowadzić do błędnej autodiagnozy przez przytaczanie szczegółowych opisów przypadków i objawów choroby, nie mogą odnosić się w formie nieodpowiedniej, zatrważającej lub wprowadzającej w błąd do wskazań terapeutycznych, nie mogą także zawierać niewłaściwych, niepokojących, mylących określeń, przedstawionych graficznie zmian chorobowych, obrażeń ludzkiego ciała lub działania produktu leczniczego na ciało czy jego części ${ }^{13}$.

Ponieważ przeciętny konsument łatwiej zapamiętuje treści, które są dla niego prostsze $\mathrm{w}$ odbiorze i łączą się z czymś wcześniej znanym, specjaliści od reklamy sięgają po dwa rozwiązania, które ułatwiaja zapamiętanie nazwy. Jest to, po pierwsze, wyjaśnianie (eksplikowanie) w reklamie informacji zawartej w budowie nazwy, a po drugie - tworzenie nazw strukturalnie przejrzystych, odwołujących się w semantyce do potocznej wiedzy medycznej. A. Gałkowski za ważny element uzupełniający nazwę produktu w tekście reklamy uważa slogan. Pisze: „Slogan jest to stałe lub okazjonalne wyrażenie (mikroakt), które utrwala informację wartościującą na temat desygnowanego przez chrematonim obiektu. Slogan bywa podany jako informacja objaśniająca (streszczająca) znaczenie chrematonimu, tzn. nakierowuje na faktyczny przedmiot desygnowany przez nazwę" (2008: 340). Przyjrzyjmy się zatem sloganom (hasłom), które pojawiają się w warstwie słownej kilku spotów reklamowych.

W reklamie środka Eliminacid usłyszeć można: „Wiele osób nie zdaje sobie sprawy, że ma zakwaszony organizm. Wyeliminuj zakwaszenie!” Hasło reklamowe jest starannie dobrane: pomaga ono pacjentowi zapamiętać nazwę oraz zrozumieć jej motywację. Uczytelnia strukturę nazwy, rozbija całość na dwie składowe: Elimin- i -acid. W ten sposób odsłania motywację, która dla przeciętnego pacjenta wcale nie musi być oczywista. Strukturalne znaczenie, które podsuwa slogan, da się przedstawić następująco: środek eliminujący (Elimin-) + kwas (zakwaszenie; -acid).

W spocie reklamowym produktu Niko-lek głos lektora powiadamia: „guma Niko-lek uwalnia leczniczą nikotynę, pozwala rzucić palenie i zachować zgrabną sylwetkę". W haśle reklamowym wyraźnie sugeruje się, że proponowany produkt to lek (coraz częściej producenci wyraźnie zaznaczają czy ich produkt jest lekiem, czy suplementem diety) oraz co jest jego substancją czynną (nikotyna lecznicza).

${ }^{13}$ Zob. Reklama produktów leczniczych, https://www.gif.gov.pl/pl/nadzor/reklama-produktowleczn/476, Reklama-produktow-leczniczych.html (dostęp 19 I 2018). 
Reklama pozwala zrekonstruować znaczenie strukturalne nazwy (czyli wynikające z budowy): to lek, który działa nikotyną (ale też pomaga w leczeniu uzależnienia od nikotyny). Innego przykładu reklamy, w której dokonywana jest eksplikacja znaczenia strukturalnego nazwy, dostarcza Positivum. W scence reklamowej kobieta, zdenerwowana kłótnią z mężem, wyrokuje, że przez to na pewno nie zaśnie. Druga pojawiająca się w tej scenie kobieta oferuje pomoc w postaci tabletek Positivum i tłumaczy, że stosuje ten specyfik regularnie, bo ,wiadomo, jaki jest Andrzej... Trzeba myśleć pozytywnie". W reklamie powtórzona jest informacja zawarta w nazwie leku, zaakcentowane jest słowo pozytywnie (przez umieszczenie na końcu wypowiedzi), skojarzone z nazwą leku. Celowe jest tu także wykorzystanie charakterystycznej dla nazw leków cząstki -um. Dzięki temu struktura nazwy dobitnie akcentuje (podobnie jak Nikolek), że proponowany produkt jest lekiem (nie zaś suplementem diety).

Z rozmowy dwóch kobiet na ścianie wspinaczkowej (przedstawionych w filmiku reklamowym) dowiadujemy się, co następuje: „Na ostatniej wizycie do pigułek dostałam Asequrellę. / - A co to jest? /_Asequrella działa osłonowo, chroni wątrobę. / - Pewnie! Trzeba się asekurować!"14. Reklamowana w spocie Asequrella nabywa dla swej nazwy motywacji w zestawieniu z sytuacją przedstawioną w filmie: dwie młode kobiety ćwiczą na ścianie wspinaczkowej i rozmawiają przy tym o asekuracji. Niektóre ujęcia celowo skupiają są na linach zabezpieczających (asekuracyjnych). „Asequrella działa osłonowo” — to hasło, wsparte ilustrująca je scenką wspinaczkową, ma pozostać w pamięci adresata.

Ważne dla skuteczności analizowanej teraz reklamy wydaje się użycie dialogu. Izabela Łuc pisze: „w związku z tendencjami języka do permanentnego podlegania zmianom, copywritherów uczy się, że reklama powinna zawierać elementy zwykłej rozmowy”. Zdaniem badaczki „elementy zwykłej rozmowy” uzyskuje się dzięki wykorzystaniu naturalnie brzmiących wypowiedzi, pochodzących z codziennego życia (por. Łuc 2009: 347).

W nazwie Wzrostan została wykorzystana cząstka nazwotwórcza -an, często stosowana w nazwach leków. Jej dość wysoka frekwencja w nazwach leków sprawia, iż łatwo można określić typ produktu, z jakim mamy do czynienia. Hasło reklamowe: „Wzrostan zawiera niezbędne składniki do prawidłowego wzrostu dzieci i młodzieży" uczytelnia (eksplikuje) informację umieszczoną w nazwie. Podobnie czytelna staje się nazwa Apetiblock. Wykorzystano w niej angielski element -block. $Z$ hasła reklamowego, które pada w trakcie spotu, można dowiedzieć się o działaniu oferowanego specyfiku: „blokuje apetyt i chęć podjadania”. Inną nazwą, w której wykorzystano angielski element -block, jest Perspiblock. Hasło reklamowe eksplikuje znaczenie strukturalne nazwy i zarazem ,gra” dwuznacznością formy potem

${ }^{14}$ Wydaje się, że celowa zamiana określenia tabletka antykoncepcyjna na słowo pigutka jest przejawem zjawiska, które określam jako potoczną metonimizację nazw leków i omawiam w innym miejscu. 
(przysłówek i narzędnik od pot): „Zablokuj i nie martw się potem!”. Wprowadzenie cząstki angielskiej jest niewątpliwie przejawem kolokwializacji. Język ten jest dziś bardzo popularny, a z pewnością dużo bardziej popularny od występującej w tradycyjnych nazwach leków greki i łaciny. Jeszcze innego przykładu skolokwializowania dostarcza reklama Limitek. W Limitkach strukturalnie znacząca jest forma zdrobnienia od słowa limit. Z reklamy środka dowiadujemy się, że chodzi o produkt przeznaczony dla dzieci („ograniczają chęć spożywania słodyczy u dzieci”). Cecha strukturalna nazwy (zdrobnienie) oddaje zatem przeznaczenie specyfiku dla dzieci. Forma liczby mnogiej (limitki) w jakiś sposób nawiązuje do dziecięcego myślenia, w którym lek utożsamiany jest z postacią, w jaki się go podaje (limitki to tabletki, które blokują apetyt na słodycze).

Analiza przywołanych nazw pozwala mówić o dwu stopniach kolokwializacji. Jeden z nich nazwałabym „łagodnym”, drugi — „radykalnym”. W pierwszym wypadku nazwy leków zdają się nawiązywać do tych „tradycyjnych”, mają podobną do nich budowę. Trudniejsze elementy takich nazw (np. te pochodzące z greki i łaciny) są eksplikowane (objaśniane) w hasłach reklamowych. Typ „radykalny” to taki, w którym lokowałabym nazwy składające się ze słów z podstawowego zasobu leksyki użytkowników języka. Mam tu na myśli nazwy wskazujące na przeznaczenie specyfiku: na odciski, na oczy, na pot itp. Oczywiście, nie jest możliwe wytyczenie ostrej granicy pomiędzy tymi grupami, przejście pomiędzy nimi wydaje się płynne.

Na koniec zanalizuję jeszcze jedną nazwę. W objaśniającym ją przekazie reklamowym pojawia się to, co na wstępie określiłam jako wystylizowanie języka reklamy na potoczne (i ocierające się o granicę wulgarności) mówienie o ludzkiej fizjologii. Wyrazistą stylizację na potoczność znajdziemy w materiale reklamowym produktu Lokomotiv. Nazwa jest łatwa do zapamiętania. Jednoznacznie skojarzyć ją można ze środkami lokomocji. W reklamie słyszymy rozmowę dwóch mężczyzn, którzy jadą z dziećmi samochodem: „— Ożeż ty, a ja Maćka tabletek na podróż w ogóle nie wziąłem... / - Niech weźmie Lokomotiv. Ania mówi, że jest najlepszy. Młody po nim nie haftuje i nie jest zmulony”. Głos spoza kadru dodaje: „Lokomotiv — bezpieczna podróż bez skutków ubocznych”. Głos z kadru używa polszczyzny standardowej, może nawet nieco sztucznej i urzędowej. Za to bohaterowie scenki mówią tak, jak ci, którzy bezpośrednio zetknęli się z objawami kinetozy. Dla nich „skutki uboczne” podróży to po prostu „haftowanie” i ,zmulenie".

Nazwy leków poddają się kolokwializacji i zaczynają być coraz bardziej podobne do nazw innych produktów, które w obfitości znajdujemy na rynku. Możemy dziś obserwować dwa równolegle postępujące procesy: rozszerzania rejestru leków dostępnych poza aptekami oraz postępującego „utowarowienia” leków. Producenci lekarstw i autorzy materiałów reklamowych stosują różne zabiegi marketingowe, dzięki którym nazwy mają stać się łatwiejsze do zapamiętania i bardziej rozpo- 
znawalne przez klientów. Hasło reklamowe, odpowiednio powiązane z nazwą, ma napędzać sprzedaż produktu, powodować, że nazywany produkt nie zginie wśród wielu mu podobnych. Nazwy kolokwialne mają podnosić atrakcyjność oferowanego produktu przez to, że apelują do czegoś, co można określić mianem kryzysu zaufania do specjalistów. Kultura współczesna dopuszcza do głosu nie tylko lekarzy-specjalistów, ale też rozmaitych przedstawicieli tzw. medycyny niekonwencjonalnej. Dziś — po latach dyktatu medycyny zawodowej — do łask zdaje się wracać tzw. medycyna ludowa. Liczy się znów mądrość życiowa, której nie poświadczają żadne dyplomy. W tych nowych warunkach nazwy skolokwializowane (w przeciwieństwie do tradycyjnych) zdają się zyskiwać na skuteczności. We wszystkich analizowanych tutaj nazwach zawarta jest bowiem sugestia: jesteś dla siebie najlepszym lekarzem! W każdej zawiera się też retoryczne pytanie: czy ktoś zna twoje ciało lepiej niż ty?

\section{LITERATURA}

Bralczyk J. 2004: Język na sprzedaż, Gdańskie Wyd. Psychologiczne, Gdańsk.

Gałkowski A. 2008: Chrematonimy w funkcji kulturowo-użytkowej. Onomastyczne studium porównawcze na materiale polskim, włoskim, francuskim, Wyd. UŁ, Łódź.

Łuc I. 2009: „Padaka trafita ceny” — moda językowa w reklamie $i$ „,modny język reklam w codziennej komunikacji”, [w:] A. Rypel, D. Jastrzębska-Golonka, G. Sawicka (red.), Język. Biznes. Media. „Prace Komisji Językoznawczej Bydgoskiego Towarzystwa Naukowego” XIX, Bydgoszcz, s. 345$-356$.

Moskal W. 2013: Łykamy dwa miliardy tabletek przeciwbólowych, „Gazeta Wyborcza”, 17 I, http:// wyborcza.pl/1,75400,13249330,Lykamy_dwa_miliardy_tabletek_przeciwbolowych.html (dostęp 6 II 2018).

Motyl M.: Reklamy leków stużq biznesowi, a nie edukacji, www.rynekaptek.pl/marketing-i-zarzadzanie/ reklamy-lekow-sluza-biznesoei-a-nie-edukacji.html (dostęp 12 XI 2016).

Połowa pacjentów ignoruje zalecenia lekarzy, http://www.rynekaptek.pl/farmakologia/farmakoterapiapolowa-pacjentow-ignoruje-zalecenia-lekarzy,17307.html (dostęp 24 V 2017).

Reklama produktów leczniczych, https://www.gif.gov.pl/pl/nadzor/reklama-produktow-leczn/476,Reklama-produktow-leczniczych.html (dostęp 19 I 2018).

Rozporządzenie Ministra Zdrowia z dnia 21 listopada 2008 r. w sprawie reklamy produktów leczniczych, DzU, nr 210, poz. 1327.

Decyzja nr GIF-P-R-450/9-3/JD/14 Głównego Inspektoratu Farmaceutycznego.

Decyzja nr GIF-P-R-450/46-2/JD/14 Głównego Inspektoratu Farmaceutycznego.

Ustawa Prawo farmaceutyczne z dnia 6 września 2001 r., DzU, 2008, nr 45, poz. 271, z późn. zm. 


\section{COLLOQUIALIZATION OF DRUG TRADE NAMES. ABOUT A CERTAIN} NEW ONOMASTIC TENDENCY

\section{SUMMARY}

The article is devoted to new onomastic tendency i.e. colloquialization of drug trade names. The author tries to draw attention to the problem of simple vocabulary being now used in drug naming. What also seems interesting is the phenomenon of colloquialization of drug advertising.

Keyw ords: chrematonyms, trade name of the medicinal product, trade name of the dietary supplement, medical education 